\title{
Human Life in the Arctic
}

\section{Ralph S. Tarr}

To cite this article: Ralph S. Tarr (1912) Human Life in the Arctic, Journal of Geography, 10:5, 145-151, DOI: $10.1080 / 00221341208985672$

To link to this article: http://dx.doi.org/10.1080/00221341208985672

$$
\text { 曲 Published online: } 20 \text { May } 2008 .
$$

Submit your article to this journal 전

Џll Article views: 2

Q View related articles $\sqsubset$ 


\title{
THE JOURNAL OF GHOGRAPHY
}

VOLUME X JANUARY, 1912 NUMBer 5

\section{HUMAN LIFE IN THE ARCTIC}

\author{
By RALPH S. TARR, \\ Cornell University, Ithaca, N. Y.
}

T $N$ the Northern Hemisphere the continents extend into the Arctic zone 1 so as to nearly enclose the Arctic Ocean which spreads over the north polar region, contrasting strikingly with the conditions in the Southern Hemisphere, where a continent, surrounded by water, occupies the south polar region. In the far south the water has served as a barrier and the Antarctic is consequently an uninhabited region; but in the encircling northern land, a continuation of a region readily habitable, it is not unnatural that human beings should have pushed the zone of habitation to the very northern border of the continents.

Thus it happens that there is a sparsely settled coastal fringe all the way from northern Norway, across northern Asia and North America to Greenland; but in the short space between Furope and Greenland there is no aboriginal population either in Iceland or Spitzbergen, the ocean barrier having been effective in preventing the spread of primitive people to these islands. From the coastal fringe there are narrow ribbons of population along the larger rivers; but over large areas between the rivers, back from the coast, there are few, if any, human beings. In America the interstream areas of the Arctic region are practically unoccupied; but in northern Eurasia, where the aboriginal population has learned the use of the reindeer, this zone has been found favorable to a sparse population; and in the extreme west of Furasia the modification of the Arctic climate by the warm west winds has made possible the Lapland settlements of northern Norway, Sweden and Russia.

\section{IIMITATIONS TO HUMAN LFFE}

The sparseness of this Arctic population, and its distribution, are due to the limited food supply found in such high latitudes, not directly to the cold and winter darkness; for, given food and materials for clothing and shelter, man can survive amid even the most adverse climatic conditions known on the lands.

One of the chief limitations to human life in the frigid zone is the fact that, throughout the greater part of the land in high latitudes, the 
climatic conditions are unfavorable to the growth of food-producing plants. There are local exceptions, as on the coast of Norway where grains are raised within the Arctic zone; but, in general, all forms of agriculture are prohibited. It is true that the native plants supply a few berries that have some value as a partial food supply; but these cannot be considered basal in importance. The soil is normally frozen to a great depth, thawing out only at the very surface during the summer months, and this frozen state is unfavorable to the growth of trees, although on the southern margin of the tundra scrub forests exist in some portions of the Arctic zone, as for instance in Alaska and in Lapland. Normally the tundra flora consists of annual and perennial plants with a few low shrubs and many mosses and lichens.

This herbage suffices to support life of scattered herbivorous animals, notably the reindeer and musk-ox among the mammals, and the ptarmigan among the birds; and a few carnivorous animals preying upon these are also found. But there is far too little of such land life to furnish a steady food supply for even a sparse population. Thus neither the plant nor the animal kingdom offers opportunity for sustenance on the Arctic lands.

When the fish in the rivers are added to such food supply as can be obtained from the land animals and plants, there is sometimes a sufficient food basis for scattered aboriginal life. This is one of the chief reasons why there are ribbons of population along the larger streams, the other reason being the opportunity that the rivers offer for free movement, thus enlarging the territory from which the food supply may be drawn.

THE SEA AS A SOURCE OF FOOD

In striking contrast to the land, there is a marked development of animal life suitable for food along the coast; and this, together with the scanty supply of food from land animals and plants, is the basis upon which the Eskimo and other northern people depend. The Arctic coast in summer is the seat of abundant and varied life. Minute animalculae abound in these cold waters, as is proven by the fact that the largest of animals, the whale, subsists upon them; and many lowly forms of life exist on the shallow sea bottom, forming the food supply for swimming and diving animals, including the seal and walrus among the mammals, and large numbers of swimming and diving birds. To these may be added the polar bear which preys primarily upon the seal.

The larger mammals exist in sufficient numbers to furnish the main support of the coastal people, though they depend in part upon fish and upon the sea birds which exist in vast numbers, nesting upon the rocky cliffs and barren islands. The abundance of this bird life in summer is almost inconceivable; but by the time the winter cold has sealed the Arctic seas most of the birds have migrated to southern regions where open water permits them to obtain their normal food supply. 


\section{THE UNCIVILIZED ESKIMO}

Among the Arctic people the Eskimos offer the best illustration of the influence of geographic environment. These people, numbering perhaps 30,000 in all, are spread in scattered settlements from just west of Bering Straits to the eastern coast of Greenland, fringing the mainland and also occupying the coast of some of the islands. Formerly throughout this area, and at present in those places out of reach of the influence of white men, the Eskimos have been engaged in one of the most serious struggles against adverse geographic conditions of any people in the world.

To the land they can look only for a very small contribution in the form of berries and the scattered land animals. They must look out to the sea not only for the bulk of their food, but also for materials for clothing and shelter. Only by the hardest struggle, constantly kept up, and by the exercise of intelligence, energy and ingenuity, is it possible for them to maintain life amid such surroundings. Since the food supply is shifting and uncertain, it is not usually possible for them to have fixed homes; they must ever be ready to move from point to point when the food supply fails. Consequently, though not strictly nomadic, they are migratory within a narrow range.

This necessary mode of life of the Eskimo places a distinct limitation upon the amount of property that can be accumulated, for anything in excess of actual needs must be left behind when the time for moving comes. The boat (kayak) which the men use in hunting, the large skin boat (oomiak) in which the women and children move the property from place to place, a few skins for cover and for tents, the clothing which they wear, and a few simple implements constitute the outfit of Eskimo communities. The winter home is of ice or snow, suitable not merely because of the abundant supply, but also because it is easily worked and quickly built into the igloo form, and because it furnishes the best of shelter against the Arctic cold. The summer home consists of a few skins thrown over upright supports, usually the bones of large animals; easily put together, easily taken down, and easy to transport. For fuel in winter the blubber of the seal or walrus suffices, and in summer little or no fuel is used, since meat is relished in the raw state.

To hunt their food supply upon the sea it is necessary to have provision for expeditions both in summer and in winter. This necessitates a boat for summer, when the ice is partly or wholly absent from the sea, and for winter a sled to be drawn over the frozen surface. For the latter purpose dogs are used as motive power, and were it not for the fact that these people have learned to make use of the dog as a draft animal it is highly probable that life could not be sustained over most of the area now occupied by the Eskimo. 
In the making of the boats, sleds, and implements of the chase, very great ingenuity is shown in utilizing the limited resources to meet their needs. The boat is made of skin wrapped around a frame of bone or, where possible, of wood that has drifted ashore. The hunting boat, or lsayak, is long and narrow and can be propelled through the water with great rapidity, this being necessary in the seal hunt. Since swiftnes: interferes seriously with stability, and consequently with safety, the boat is decked over with skin, excepting at one point in the middle where a round hole is left open for the Eskimo to sit in; and when he has taken his place in the kayak, the skin is drawn around his waist so that he essentially becomes an integral part of the boat, propelling it with his double-bladed paddle. Under such conditions an upset is not accompanied with the same danger as in an open boat, for the occupant can skillfully right the overturned kayak which, because of its deck, ships no water. In the Alaskan region, the Eskimo use the bidarki, a modification of the kayak, with two or more holes instead of one. The woman's boat, or oomiak, also a skin boat stretched upon a bone or wood frame, is a far clumsier boat and is used only for the slow process of carrying the camp outfit: and the women and children, from point to point.

'The Eskimo in his kayak carries spears for birds, fish and seal, all. ingeniously contrived, and mainly made of bone, ivory and sinew. $\mathrm{He}$ must travel rapidly, and far and wide, often amid floating ice, and often exposed to the danger of winds and storms. There is constant effort, and abundant danger.

The winter sled is also an ingenious contrivance made of bone, or wood and bone, fastened together with thongs, shod with bone or ivory, and attached to the dog team with sinew. The sled is moved freely about over the frozen sea, and long journeys must often be made. It is during this season that the greatest danger comes to the Eskimo hunter, for his prey can be found only at those holes or breaks in the ice where it rises to the surface to breathe, and these he must locate and patiently watch. During this hunting seaeson, the bitter cold and the darkness of the winter night are added to the difficulties that the Eskimo must endure. Many are the times when a hunter fails to return from the winter chase, or, after several days of the hardest work, returns without success. Many are the times that it becomes necessary to move the village, and not uncommonly starvation stares the Eskimo in the face.

It is not to be wondered at that; under such conditions, there has developed a socialistic habit of sharing property; for a seal brought in by a successful hunter may be necessary to save the life of the unsuccessful. Nor is it to be wondered at that when starvation is imminent the old and weak are first allowed to perish. Nor is it remarkable, as has been asserted, that death comes to Eskimo men mainly from accident, rather than disease; and that old men are not numerous in Eskimo colonies. 
Under these conditions of life it naturally follows that there can bo no large settlements, for success depends upon scattering, otherwise the food supply in a locality would soon be exhausted. It also follows that there must be frequent movements in search of better hunting grounds. The development of the idea of individual property is thus checked, and even the accumulation of property by a group is also undesirable. Naturally, also, there can be no efficient tribal organizations, and no chiefs or rulers. The natural mode of life is in small, migratory communities, keeping within a somewhat restricted area, each family being in a measure independent of the others, though subject to draft upon their resources if they are more successful than their associates. Also, the method of hunting is naturally individual, for the prey is scattered, it must be sought in as many localities as possible, and when located it must be swiftly followed. For these purposes, individuals, each in a swift boat, offer the greatest chance of success.

Such a life necessarily breeds hardiness, courage, cunning, and intelligent ingenuity; but both the severe struggle for existence and the necessary mode of life are adverse to the internal development of civilization. To the savage of the humid tropical zone life is too easy; to the Eskimo it is too hard, and the energies are used up in securing the barest necessities from a region by no means too bountiful, leaving little time or opportunity for self improvement.

\section{TIIE GREENLAND ESKIMO}

Along a portion of the western coast of Greenland, the Eskimos have been brought under control of a European nation-Denmark-and this has naturally brought about a very material modification in the moris of life of these Arctic people. It would take much more space than is here available to point out the full extent of the modification, though some points which stand out prominently may be briefly stated.

One of the most striking modifications is in the introduction of modern civilized weapons, notably the rifle, which has extended the power of the Eskimo as a hunter, but has had the disadvantage of killing game faster than had previously been the case. This slaughter has been encouraged by the demand of the Danes for some kind of financial return for their colonial venture. Thus seal skins, bear skins, walrus irory, seal oil and eiderdown are obtained in excess of the needs of the inhabitants.

A second notable modification that has been introduced is in the mode of living. There is available an increased variety of material for food, clothing and shelter to be purchased from the Danes with the excess supply from the chase. European fabrics enter to some extent into the native clothing; they have acquired a taste for certain kinds of European food; and wooden houses have in part replaced the winter homes of snow 
and ice and the summer tents of skin. Together with these changes has naturally come a checking of the migratory habit, and the Eskimos have tended to gather into villages, some of which have attained considerable size. Here they erect houses of wood, stone, or turf; and naturally, with the growth in size of the community, and in its stability, there has developed the necessity of some form of government, encouraged and devised, to be sure, by the Danes. Naturally, also, the idea of individual property has developed and Greenland Eskimos even with bank accounts are not unknown.

Thus in Greenland the full effect of geographic influence is modified by the superior position of civilization; for here, as elsewhere, civilized man has shown his great capacity to orercome adverse climatic conditions. With the new life that the Greenland Eskimos have learned, with the loss of skill in the use of their primitive weapons that has naturally followed, and with the decrease in their natural food supply that has resulted from the use of the deadly weapons of civilization, it is doubtful whether these people could continue to live in the present numbers if the support of the Danish government, and the means of transportation which it provides, were withdrawn. It is said that from a financial standpoint this Greenland colonial venture is a failure, and that it is maintained in spite of this fact because disaster would necessarily result if the Eskimo were now to be abandoned.

\section{ARCTIC AGRICULTURAI, POPULATION}

On the very southern fringe of the Arctic zone, there are several localities where agriculture is possible, the hardier grains being raised, and domestic animals being used as a partial food supply. This phase of Arctic life finds its best illustration in Lapland where, as already noted, the reindeer extends the power of man to live amid such adverse climatic conditions. It is probable that similar life is possible in portions of Alaska, in the neighborhood of the Arctic Circle.

The densest population in the Arctic zone is in the northern part of Norway, where the Arctic climate is greatly moderated by the winds which blow so steadily from the warm ocean waters that spread along the northwestern European coast. Here we find such towns as Tromsö and Hammerfest, and many villages and hamlets besides. The agricultural lowlands are planted in hardy grains and vegetables, while cattle, sheep and reindeer graze upon the mountain slopes; but here also, as in other Arctic lands, the ocean is one of the main sources of food supply. The fiords and shallow banks are rich in food fish, and even the agricultural coastal population is, in large part, a fishing population also. In addition, a goodly number depend for their sustenance, mainly or entirely, upon the products of the sea. 


\section{THE INFLUENCE OF MINERAT, DEPOSITS}

When valuable mineral deposits are discorered a wholly new element is introduced into the problem of human occupation of the Arctic zone. This finds an excellent illustration also in Lapland, where a thriving town has quickly grown as a result of the development of the remarkable iron mines of Kiruna in Sweden. Even in a land as far north as Spitsbergen a town, under the name of Longyear City, has been established in latitude $78^{\circ} \mathrm{N}$. because of the beginning of development of the coal beds.

Mining in Arctic North America has not as yet made great progress, though there are scattered settlements and individual miners working in various parts of Alaska north of the Arctic Circle. Most of this mining work is in placer deposits and here, as well as over a large section south of the Arctic Circle, the climatic conditions have introduced serious difficulty into this form of mining; for the ground is frozen to a great depth, and before the precious metal can be removed it is necessary to first thaw the ground in order that the gravels may be washed away from the heavy metal.

It cannot be doubted that if rich deposits of gold are discovereil in Arctic Alaska, a population will establish itself there and remain as long as the metal supply warrants. Such habitation, however, is exceptional, and is made in spite of climatic conditions, solely because of the mineral wealth; for, with the artificial aids of modern civilization, man is easily able to overcome even the most adverse climatic conditions.

\section{GENERAL CONCIUSYON}

Thus, because of the climate, working indirectly through the food supply upon which human beings depend, the Arctic zone is sparsely inhabited. Such occupation as is found depends in general upon the presence of a food supply in the neighboring waters and is, therefore, mainly confined to the coast line and to the rivers. The exceptions are where local climatic conditions are unusually favorable, as on the coast of Norway, and where valuable mineral deposits attract man because of the local wealth.

Under all these phases of Arctic life man is forced into a struggle to overcome adverse climatic conditions, as his fellow man is in the desert and in the lofty mountains. In each case, as an outcome of the struggle, the influence of the environment leaves its stamp on the man himself and upon his habits and customs. In few parts of the earth is this stamp more clearly and strikingly recognizable than among the uncivilized Arctic people. They are almost wholly creatures of their environment, and almost their every act and custom is a response to some environmental influence. 